\title{
Renewable Energy Resources - Onshore/Offshore Wind Energy
}

\author{
Pinson, Pierre; Giebel, Gregor; Clausen, Niels-Erik
}

Published in:

Climate Vulnerability

Link to article, DOI:

10.1016/B978-0-12-384703-4.00310-5

Publication date:

2013

Link back to DTU Orbit

Citation (APA):

Pinson, P., Giebel, G., \& Clausen, N-E. (2013). Renewable Energy Resources - Onshore/Offshore Wind Energy. In R. Pielke (Ed.), Climate Vulnerability : Understanding and Addressing Threats to Essential Resources (Vol. 3, pp. 53-64). Elsevier. https://doi.org/10.1016/B978-0-12-384703-4.00310-5

\section{General rights}

Copyright and moral rights for the publications made accessible in the public portal are retained by the authors and/or other copyright owners and it is a condition of accessing publications that users recognise and abide by the legal requirements associated with these rights.

- Users may download and print one copy of any publication from the public portal for the purpose of private study or research.

- You may not further distribute the material or use it for any profit-making activity or commercial gain

- You may freely distribute the URL identifying the publication in the public portal

If you believe that this document breaches copyright please contact us providing details, and we will remove access to the work immediately and investigate your claim 


\title{
CLIMATE VULNERABILITY \\ UNDERSTANDING AND ADDRESSING THREATS TO ESSENTIAL RESOURCES
}

EDITOR-IN-CHIEF

Roger A. Pielke, Sr.

University of Colorado at Boulder, Boulder, CO, USA

VOLUME 3

\section{VULNERABILITY OF ENERGY TO CLIMATE}

\author{
VOLUME EDITOR \\ George Kallos
}

School of Physics, University of Athens, Athens, Greece 


\section{Volume 3 - Vulnerability of Energy to Climate}

\section{Energy Resources and Policy Under Climate Change Conditions}

Preface - Vulnerability of Energy to Climate

Resources and Resource Availability

3.01 Climate and Energy Vulnerability in Coastal Regions: The Case for US Pacific and Northeast Corridor Coastal Regions

J Gonzalez Cruz, P Sequera, Y Molina, R Picon, J Pillich, AT Ghebreegziabhe and B Bornstein

3.02 Energy Resources and Policy: Vulnerability of Energy Resources and Resource Availability - Fossil Fuels (Oil, Coal, Natural Gas, Oil Shale)

CA Miller

3.03 Renewable Energy Resources - Onshore/Offshore Wind Energy

P Pinson, G Giebel and N-E Clausen

3.04 Renewable Energy Resources - Ocean Energy: Wind-Wave-Tidal-Sea Currents

SC Pryor and RJ Barthelmie

3.05 Biomass

BM Fekete

3.06 Vulnerability of Solar Energy Resources under Climate Variability DI LePoire

Energy Production, Conversion, Transmission \& Distribution, Policy, Planning and Mitigation Processes - General Considerations

3.07 Energy Production, Conversion, Transmission, and Distribution, Policy, Planning, and Mitigation Process - General Considerations: Infrastructure Vulnerability and Climate $N$ Sarafoglou and $M$ Kafatos

3.08 Climate and Energy Production - A Climate Services Perspective 
3.09 Energy Market Fundamentals

A Papalexopoulos

3.10 Energy Networks

AG Tsikalakis and ZN Vrontisi

MA Lange

3.12 Energy Buildings and Urban Environment

DJ Sailor

3.13 Transportation and Energy

3.14 Energy Production, Conversion, Transmission and Distribution, Policy, Planning, and Mitigation Processes - General Considerations: Large Energy Projects, Efficiency, and Vulnerability ZN Vrontisi

3.15 Transmission Grid Fundamentals 